\section{Поширеність депресивних , розладів серед хворих на цүкровий діабет, які мешкають у зоні АТО та в інших областях України}

\section{С.М. Ткач}

ДУ «Інститут ендокринології та обміну речовин ім. В.П. Комісаренка НАМН України»

* Адреса для листування (Correspondence): ДУ «Інститут ендокринології та обміну речовин ім. В.П. Комісаренка НАМН України», вул. Вишгородська, 69, м. Київ, 04114, Україна. E-mail: Dr_Tkach@ukr.net

(C) C.M. Ткач 
Оригінальні дослідження

випадків. Негативні соціальні чинники, пов'язані з мешканням у зоні АТО протягом 6-18 міс., суттєво не вплинули ані на частоту, ані на ступінь депресивного синдрому, що може вказувати на незалежний характер депресивних розладів на тлі ЦД.

Ключові слова: цукровий діабет, депресивні розлади, зона АТО.

За даними досліджень останніх років, у хворих на цукровий діабет (ЦД) депресію виявляють вдвічі частіше, ніж у загальній популяції - у 29,2-46,2\% випадків [1-4]. Важливість вчасної діагностики депресивних порушень у хворих на ЦД обумовлено не лише iï негативним впливом на якість життя паці-

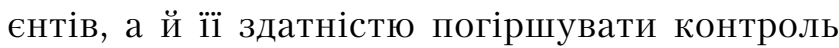
глікемії [5-7].

Відомо, що депресія може виникати внаслідок не лише ендогенних, але й психогенних причин, як реакція на зовнішню ситуацію - так звана «реактивна депресія» [8]. До останніх належать надзвичайні ситуації, проведення воєнних дій. Ці дії здатні впливати не лише на їх безпосередніх учасників, а й на свідків цих подій та осіб із числа мирного населення, а також тимчасово переміщених осіб, провокуючи розвиток психогенних патологічних реакцій, психогенних невротичних станів, реактивних психозів, коли можуть спостерігатися депресивний синдром і депресивні розлади. Проведення АТО торкнулося багатьох людей України, в тому числі хворих на ЦД. Проте досі залишається невивченим вплив цієї надзвичайної ситуації на психоемоційний стан пацієнтів із ЦД. Тому метою даного дослідження була оцінка поширеності депресивного синдрому серед хворих на ЦД, які мешкають у зоні проведення АТО та поза зоною ведення воєнних дій.

\section{Матеріал і методи}

Обстежено 253 хворих на ЦД -80 пацієнтів із ЦД 1-го типу (ЦД1) і 173-2-го типу (ЦД2), віком від 18 до 82 років, 167 жінок і 86 чоловіків, які перебували на стаціонарному лікуванні в відділенні діабетології ДУ «Інститут ендокринології та обміну речовин ім. В.П. Комісаренка НАМН України». Серед них було 30 пацієнтів, які приїхали на лікуван- ня із зони проведення АТО - мешканці різних районів Донецької та Луганської областей, і 223 хворих з інших областей України. Термін мешкання в зоні АТО на момент обстеження складав від 6 до 18 місяців.

Серед 30 мешканців зоні АТО були 21 жінка та 9 чоловіків, середнім віком $53,4 \pm 2,8$ року, 9 з яких мали Цд1 і 21 пацієнт - ЦД2. Серед решти 223 пацієнтів, мешканців інших областей України (поза зоною АТО), було 146 жінок і 77 чоловіків, середнім віком 54,4 $\pm 0,9$ року, 71 з яких мали ЦД1 і 152 - ЦД2.

Переважна більшість пацієнтів перебували в стані декомпенсації. Всім хворим проведено цуркознижувальну терапія препаратами інсуліну, пероральними препаратами або їх комбінацією. У переважної більшості пацієнтів мали місце ускладнення ЦД: полінейропатія, ретинопатія, нефропатія, ангіопатія нижніх кінцівок.

Усім хворим проведено опитування на предмет виявлення депресивних розладів 3 одночасним використанням найбільш застосовуваних у психіатричній практиці шкал опитування: Бека та PHQ-9. Результати опитування за шкалою Бека оцінювали в балах та інтерпретували згідно з існуючими рекомендаціями: 0-9 балів - відсутність депресивних симптомів, 10-15 - легка депресія (субдепресія), 16-19 - помірна, 20-29 балів - виражена (середньої тяжкості), 30-63 бали - тяжка депресія.

Результати шкали опитування PHQ-9 також підраховували в балах і розцінювали згідно з рекомендаціями: 1-4 бали - відсутність депресії, 5-9 - мінімальні прояви депресії, 1014 балів - легка депресія, 15-19 балів - депресія середнього ступеня, 20-27 балів - тяжка депресія.

Результати обробляли статистично із застосуванням критерію t Стьюдента 3 визначенням показника вірогідності різниці (р). 


\section{Результати та обговорення}

Серед усіх 253 обстежених із ЦД за результатами опитування депресивну симптоматику визначено за шкалою Бека в 166 (65,6\%) пацієнтів, за шкалою PHQ-9 - у 155 (61,3\%) хворих.

Хворі на ЦД із депресивним синдромом скаржилися на плаксивість, порушення сну (прокидалися на 1-2 години раніше звичайного, їм важко було знову засинати або зовсім не могли заснути), відзначали зменшення зацікавленості робити будь-що і зниження задоволеності від результатів своєї діяльності. Пацієнти були пригніченими, мали відчуття втоми, тривоги, розчарування, дратівливість, почували себе засмученими та помічали за собою зниження рухливості та швидкості розмови, втрату або зниження сексуального інтересу.

За даними опитування 230 хворих, які мешкали в областях України поза зоною АТО, за шкалою Бека депресивні розлади зареєстровано в 150 з них (67,3\%). Водночас серед 30 обстежених, які мешкали в зоні АТО, депресивну симптоматику виявлено в 16 (53,3\%) (p>0,1). За результатами опитування цих же 230 хворих за шкалою PHQ-9 депресивні розлади зареєстровано в 136 пацієнтів, що склало 61,0\%. За результатами опитування хворих із зони АТО за шкалою PHQ-9 депресивну симптоматику виявлено в 19 (63,3\%) із 30 обстежених.

Серед 150 хворих із депресією, які мешкали в областях поза зоною АТО, за даними опитування за шкалою Бека діагностовано депресивний синдром різного ступеня: у 76 (50,2\%) - легкого, у 33 (22,0\%) - помірного, у 32 (21,3\%) - вираженого, у 9 (6\%) пацієнтів - тяжкого ступеня. У решти 73 хворих (32,7\%) депресії виявлено не було. За результатами опитування хворих, які мешкали поза зоною АТО, за шкалою PHQ-9 у 78 (57,4\%) осіб знайдено мінімальні прояви депресії, у 37 (27,2\%) - легку депресію, у 12 (8,8\%) - виражену (середньої тяжкості), у 9 (6,6\%) - тяжку депресію. Порушень психоемоційного стану в решти 87 хворих не знайдено.

У 16 хворих із зони АТО з виявленою депресією за шкалою Бека спостерігали депресивну симптоматику різного ступеня: у 8 легкого, у 2 - помірного, у 4 - вираженого, у 2 пацієнтів - тяжкого. У решти 14 хворих депресії виявлено не було. За результатами опитування хворих із зоні АТО за шкалою PHQ-9 у більшості з них (9 пацієнтів) знайдено мінімальні прояви депресії, у 7- легку депресію, в 1 - виражену (середньої тяжкості), у 2 хворих - тяжку депресію.

Проведений статистичний аналіз порівняння результатів опитування пацієнтів, які мешкають у зоні ATO та пацієнтів, які мешкають поза її межами, ані за шкалою Бека, ані за шкалою PHQ-9 різниці не виявив (p>0,05). Додатковий аналіз у групах також показав відсутність статистичної різниці в розподілі пацієнтів за ступенем тяжкості депресивних проявів між хворими із зони АТО та тими, які мешкають в інших регіонах України ( $>>0,05)$.

Отже, за результатами проведеного дослідження депресивні розлади зареєстровано в більшості стаціонарних хворих на ЦД у $61,3 \%$ і 65,6\% випадків відповідно за шкалами PHQ-9 і Бека. Отримані високі показники частоти депресивних розладів серед обстежених можуть бути обумовленими тим, що до стаціонару в більшості випадків госпіталізуються пацієнти з найтяжчим перебігом ЦД.

За отриманими даними в переважної більшості пацієнтів - у 72,4-84,6\% випадків спостерігали депресію легкого та помірного ступенів, що є характерними для депресивних порушень у хворих на ЦД [9].

Відсутність статистичної різниці в поширеності депресивних розладів серед хворих на ЦД, які мешкають у зоні АТО, із результатами пацієнтів, які мепшкають за межами ведення військових дій, може свідчити про відсутність суттєвого додаткового впливу соціальних чинників. Відчуття тривоги, страху, пригніченості, емоційний стрес, занепокоєння за долю рідних і близьких є типовими для людей, які опинилися в зоні військового конфлікту. Проте, на відміну від хворих на ЦД, вони не мають тривалих метаболічних та органічних порушень, характерних для цього захворювання. Водночас, у хворих на ЦД із депресивними розладами, як свідчать останні дослідження, на тлі тривалих метаболічних порушень мають місце суттєві органічні ураження головного мозку, з якими пов'язують депресію, а саме атрофія гіпокампа $[10,11]$, що, можливо, обумовлює більш стійкий і незалежний характер депресивних порушень від впливу зовнішніх соціальних чинників. 
Перебування в зоні АТО, за отриманими даними, також не призвело до посилення тяжкості існуючих в пацієнтів депресивних розладів, на що вказує відсутність суттєвої різниці в розподілі цих хворих за ступенем тяжкості депресії порівняно 3 хворими, які мешкають поза зоною ведення військових дій. Це також може свідчити про незалежний характер депресивних розладів у хворих на ЦД.

\section{Висновки}

1. Депресивні порушення $є$ досить частими в стаціонарних хворих на ЦД - 61,365,6\% - і мають у переважній більшості випадків легкий і помірний ступені.

2. Негативні соціальні чинники, пов’язані з мешканням у зоні АТО протягом 6-18 міс., суттєво не вплинули на частоту та ступінь депресивного синдрому, що вказує на незалежний характер депресивних розладів на тлі ЦД.

\section{Список використаної літератури}

1. Eker S. Prevalence of depression symptoms in diabetes mellitus. Open Access Maced. J Med Sci. 2018 Feb; 6(2):340-343.

2. Das R, Singh O, Thakurta RG, Khandakar MR, Ali SN, Mallick AK, et al. Prevalence of depression in patients with type II diabetes mellitus and its impact on quality of life. Indian J Psychol Med. 2013 Jul-Sep; 35(3): 284-289.

3. Mier N, Bocanegra-Alonso A, Zhan D, Wang S, Stoltz SM, AcostaGonzalez RI, Zuniga MA. Clinical depressive symptoms and diabetes in a binational border population. J Am Board Fam Med. 2008 May-Jun;21(3):223-33.

4. Cols-Sagarra C, López-Simarro F, Alonso-Fernández M, Mancera-Romero J, Pérez-Unanua MP, Mediavilla-Bravo JJ, et al. Prevalence of depression in patients with type 2 diabetes attended in primary care in Spain. Prim Care Diabetes. 2016 Oct;10(5):369-75.

5. Diaconu L, Timar B, Popescu S, Timar R. Depression and metabolic control of type 2 diabetes mellitus // Diabetologia.-2013. - Vol. 56 (Suppl. 1). - P. S461-S462.

6. Plener PL, Molz E, Berger G, Schober E, Monkemoller K Denzer C, et al. Depression, metabolic control, and antidepressant medication in young patients with type 1 diabetes // Pediatric Diabetes. - 2015. - Vol. 16 (1). - P. 58-66.

7. Abuhegazy H, Elkeshishi H, Kamel A, Ismail A, Sherra K, Saleh N, Azim KA, Mokhtar D. Longitudinal effect of depression on glycemic control in patients with type 2 diabetes: A 3-years prospective study // European Psychiatry.- 2016, Suppl. Vol. 33. - P. S404-S405.

8. Михайлов БВ. Розлади психіки і поведінки екстремально-психогенного походження. Психічне здоров'я / Mental health. 2015;2(47):9-18. (Mikhailov BV. Disorders of the psyche and behavior of extreme psychogenic origin. Mental health. 2015;2(47):9-18).

9. Khan ZD, Lutale J, Moledina SM. Prevalence of depression and associated factors among diabetic patients in an outpatient diabetes clinic. Psychiatry J. 2019;2019:2083196. Published 2019 Jan 15. doi:10.1155/2019/2083196.

10. Selvarajah D, Wilkinson ID, Maxwell M, Davies J, Sankar A, Boland E, Gandhi R, Tracey I, Tesfaye S. Magnetic resonance neuroimaging study of brain structural differences in diabetic peripheral neuropathy. Diabetes Care. 2014 Jun;37(6):1681-8.

11. Moulton CD, Costafreda SG, Horton P, Ismail K, Fu CH Metaanalyses of structural regional cerebral effects in type 1 and type 2 diabetes. Brain Imaging Behav. 2015 Dec; 9(4):651-62.

(Надійшла до редакчії 10.02.2020р.)

\section{Распространенность депрессивных расстройств у больных сахарным диабетом, проживающих в зоне АТО и в других областях Украины}

\section{С.М. Ткач}

ГУ «Институт эндокринологии и обмена веществ им. В.П. Комиссаренко НАМН Украины»

Резюме. Цель - определить распространенность депрессивных расстройств у больных сахарным диабетом (СД), проживающих в зоне проведения АТО (антитеррористической операции) или других областях Украины вне зоны ведения военных действий. Материал и методы. Обследованы 253 больных СД 1-го (СД1) и 2-го типов (СД2) средней и тяжелой форм из разных областей Украины, в том числе 30 пациентов из зоны АТО, которые находились на стационарном лечении в диабетологическом отделении Гу «Институт эндокринологии и обмена веществ им. В.П. Комиссаренко НАМН Украины». Оценку психоэмоционального состояния проводили путем опроса больных по шкалам Бека и PHQ-9.

Результаты. По данным опроса больных, проживающих вне зоны АТО, депрессивные расстройства зарегистрированы у 150 из 230 больных (67,3\%) по шкале Бека и у 136 пациентов (61,0\%) по шкале PHQ-9. В то же время среди 30 обследованных из зоны АТО депрессивная симптоматика наблюдалась у 16 (53,3\%) по шкале Бека и у 19 (63,3\%) - по шкале PHQ-9, что не составило существенной разницы с группой больных из других областей Украины (р>0,05). Среди 150 больных с депрессией, проживающих вне зоны АТО, по шкале Бека был диагностирован депрессивный синдром разной степени тяжести: у 76 (50,2\%) легкий, у $33(22,0 \%)$ - умеренный, у 32 (21,3\%) - выраженный, у 9 (6\%) - тяжелый. По шкале PHQ-9 у $78(57,4 \%)$ из 150 человек найдены минимальные проявления депрессии, у $37(27,2 \%)-$ легкая, у 12 (8,8\%) - выраженная (средней тяжести) и у 9 (6,6\%) больных - тяжелая депрессия. Среди 16 больных из зоны АТО с выявленной депрессией по шкале Бека депрессивная симптоматика наблюдалась у 8 пациентов - легкой, у 2 - умеренной, у 4 - выраженной и у 2 пациентов - тяжелой степени. По шкале PHQ-9 у большинства из них (9 пациентов) найдены минимальные проявления депрессии, у 7 - легкая, у 1 - выраженная (средней тяжести) и у 2 больных - тяжелая депрессия. Проведенный анализ показал отсутствие статистической разницы в распределении пациентов по степени тяжести депрессивных проявлений между больными из зоны АТО и теми, кто жи- 
вет в других областях Украины (p>0,05). Вывод. Депрессивные расстройства являются довольно частыми среди стационарных больных СД - 61,0-67,3\% случаев. Негативные социальные факторы, связанные с проживанием в зоне АТО в течение 6-18 мес. существенно не повлияли ни на частоту, ни на степень тяжести депрессивного синдрома, что может указывать на независимый характер депрессивных расстройств при СД.

Ключевые слова: сахарный диабет, депрессивные расстройства, зона АТО.

\section{Prevalence of depressive disorders in patients with diabetes mellitus living in the ATO zone and in other regions of Ukraine}

\section{S.M. Tkach}

SI «VP Komissarenko Institute of Endocrinology and Metabolism, NAMS of Ukraine», Kyiv, Ukraine

\begin{abstract}
The aim was to determine the prevalence of depressive disorders in patients with diabetes mellitus living in the area of ATO (anti-terrorist operation) and living in other areas of Ukraine outside the area of warfare. Material and methods. We examined 253 patients with diabetes mellitus 1 and 2 types of medium and severe forms of the disease from different regions of Ukraine, including 30 patients from the ATO area who were on inpatient treatment in a diabetic ward. Assessment of psychoemotional state was performed by interviewing patients on the Beck and PHQ-9 scales. Results. According to a survey of patients living outside the ATO zone, depressive disorders were reported
\end{abstract}

in 150 of 230 patients (67.3\%) on the Beck scale and 136 patients (61.0\%) on the PHQ-9 scale. At the same time, among the 30 surveyed from the ATO zone, depressive symptoms were observed in 16 of them (53.3\%) on the Beck scale and in 19 patients (63.3\%) on the PHQ-9 scale, which did not make a significant difference with the group patients from other regions of Ukraine ( $p>0.05$ ). Among 150 patients with depression residing outside the ATO area, Beck's scale was diagnosed with depression of varying severity: 76 (50.2\%) - mild, 33 (22.0\%) - moderate, 32 (21.3\%) - severe and 9 (6\%) patients were severe. On the PHQ-9 scale, 78 (57.4\%) of 150 people found minimal manifestations of depression, 37 (27.2\%) mild, 12 (8.8\%) - severe (moderate) and 9 (6.6\%) of patients severe depression. Among 16 patients from the area of ATO with manifested depression on the Beck scale, depressive symptoms were observed in 8 patients - mild, 2 - moderate, 4 - severe and 2 patients - severe. On the PHQ-9 scale, most of them had 9 patients, found minimal manifestations of depression, 7 had mild 1 had severe depression (moderate), and 2 had severe depression. The analysis confirmed the absence of statistical difference in the distribution of patients by severity between patients from the ATO zone and those residing in other regions of Ukraine ( $p>0.05$ )

Conclusion. Depressive disorders are quite common among inpatients with diabetes, which are found in 61.0-67.3\% of patients. The negative social factors associated with staying in the ATO zone for 6-18 months did not significantly affect either the frequency or severity of the depressive syndrome, which may indicate an independent character of depressive disorders in diabetes.

Keywords: Diabetes mellitus, depressive disorders, ATO zone. 